\title{
L-arginine enhances cell proliferation and reduces apoptosis in human endometrial RL95-2 cells
}

\author{
Jonathan M Greene ${ }^{1,2,3^{*}}$, Jean M Feugang ${ }^{2,3}$, Kathryn E Pfeiffer ${ }^{2}$, John V Stokes ${ }^{4}$, Susan D Bowers ${ }^{2,3}$ \\ and Peter L Ryan ${ }^{1,2,3^{*}}$
}

\begin{abstract}
Background: L-arginine is considered to be one of the most versatile amino acids due to the fact that it serves as a precursor for many important molecules in cellular physiology. When supplemented in the diet, L-arginine can increase the number of implantation sites in mice and rats, suggesting an effect at the level of the endometrium. To this end, this study determined the effect that L-arginine has on apoptosis and cell proliferation in human endometrial RL95-2 cells.
\end{abstract}

Results: L-arginine at physiological (200 micromol/L) and supra-physiological ( 800 micromol/L) concentrations increased cell proliferation at days 2 and 4 post-treatment with a dose-dependent effect being observed on day 2 . Additionally, inhibition of nitric oxide (NO) synthase and arginase, which are responsible for the conversion of Larginine to $\mathrm{NO}$ and polyamines, respectively, reduced the proliferative effect of L-arginine. L-arginine also decreased the proportion of cells with TUNEL positive nuclei and increased the ratio of cells with healthy mitochondria compared to cells with a disrupted mitochondrial membrane potential, indicating that L-arginine prevents mitochondrial mediated apoptosis in endometrial RL95-2 cells. Furthermore, exposure to L-arginine did not affect total BAD protein expression; however, L-arginine increased the abundance of phosphorylated BAD protein.

Conclusions: In summary, L-arginine added to the culture media at physiological (200 micromol/L) and supraphysiological concentrations (800 micromol/L) enhanced endometrial RL95-2 cell proliferation through mechanisms mediated by NO and polyamine biosynthesis. In addition, L-arginine reduced endometrial RL95-2 mitochondrial mediated apoptosis through increased phosphorylation of BAD protein.

Keywords: L-arginine, Uterus, Endometrium, Cell proliferation, Apoptosis

\section{Background}

L-arginine is considered to be a conditionally essential amino acid for healthy mature mammals but an essential amino acid for young developing mammals [1], suggesting a role for arginine in tissue growth. Most dietary sources of protein contain L-arginine; however, L-arginine is found in abundant quantities in high quality plant proteins (i.e. soy proteins), and daily intake of $\mathrm{L}$-arginine for adult humans ranges from 3 to $6 \mathrm{~g}$ [2]. In addition to being incorporated into proteins and being involved in ammonia detoxification [3], L-arginine also

\footnotetext{
* Correspondence: jmg211@msstate.edu; ryan@provost.msstate.edu 'Department of Pathobiology and Population Medicine, Mississippi State University, Mississippi State, MS, USA

${ }^{2}$ Department of Animal and Dairy Sciences, Mississippi State University, Mississippi State, MS, USA

Full list of author information is available at the end of the article
}

serves as a precursor for many molecules that are important for cellular physiology, including proline, glutamate, creatine, nitric oxide (NO) and polyamines, making L-arginine one of the most versatile amino acids [4]. L-arginine is converted to NO through the action of NO synthase (NOS), while polyamines are generated through the conversion of L-arginine to ornithine via arginase [4]. Decarboxylation of ornithine by ornithine decarboxylase yields the first polyamine putrescine which serves as the precursor for the other naturally occurring polyamines spermidine and spermine through the action of spermidine synthase and spermine synthase, respectively [4].

Both polyamines and NO have vital roles in cellular processes and cell signaling. Nitric oxide and polyamines stimulate cell proliferation and have a positive effect on progression through the cell cycle [5-11]. Polyamines

\section{Biomed Central}


exert their cellular effect through their ability to bind nucleic acids and proteins [12] and have been demonstrated to promote an anti-apoptotic state in various cell lines [13]. Moreover, NO can stimulate PI3K/ Akt-1 signaling pathways [14-16] which promote cell survival. The role of L-arginine and its metabolites in cell signaling has been studied extensively in ovine $[9,17]$ and porcine [18] trophectoderm cells, with L-arginine enhancing cell proliferation through mammalian target of rapamycin (mTOR) related signaling pathways.

$\mathrm{Wu}$ et al. [19] reported an unusual abundance of Larginine in porcine allantoic fluid, suggesting a role for this particular amino acid in fetoplacental nutrition. Moreover, dietary L-arginine supplementation has been demonstrated to enhance the reproductive performance of rats [20], pigs [21], and mice [22], and recently, we have shown that dietary L-arginine supplementation increased the number of implantation sites in mice [22], which suggests an effect of L-arginine at the level of the endometrium. The endometrium has the ability to catabolized L-arginine in numerous species, including sheep [23-25], pigs [26], mice [27], rats [20], and humans [28], due to the presence of NOS and/or arginase enzymes. Moreover, L-arginine has been reported to exist in human uterine lumen flushes with the greatest concentration observed during the proliferative phase [29], suggesting a possible involvement in endometrial epithelial cell proliferation.

In the current study we used the human endometrial epithelial carcinoma cell line, RL95-2, as a model for endometrial epithelial cells. The RL95-2 cell line expresses markers found on normal human endometrial epithelial cells such as progesterone receptors, estrogen receptors $\alpha$ and $\beta$ [30], MUC1 [31], and E-cadherin $[32,33]$. Furthermore, the RL95-2 cell line has been used extensively as an in vitro model for studying the human endometrial epithelium [30,34-36]. To this end, the objective of this study was to examine the effect that Larginine may have on endometrial cell proliferation and apoptosis using the established human endometrial epithelial cell line, RL95-2, as an in vitro model for epithelial cells of the human endometrium.

\section{Methods}

\section{Cell culture}

Human endometrial carcinoma cells (RL95-2; ATCC \# CRL-1671) were acquired from the American Type Culture Collection (Rockville, MD). Cells were cultured in a humidified incubator containing 5\% $\mathrm{CO}_{2}$ using a complete growth media comprised of DMEM:F12 media (ATCC, Rockville, MD) supplemented with 10\% fetal bovine serum (FBS; Gibco, Grand Island, NY), 1\% penicillin/streptomycin (Gibco, Grand Island, NY), and 0.005 $\mathrm{mg} / \mathrm{mL}$ insulin (Sigma-Aldrich, St. Louis, MO) in order to obtain frozen stocks.

\section{Proliferation assay}

RL95-2 cells were transferred to 96 well plates $(80,000$ cells per well) in growth media for a period of $24 \mathrm{~h}$ after which they were serum and L-arginine starved for an additional 24 hours in an L-arginine free media (RPMI1640 SILAC, Sigma-Aldrich, St. Louis, MO). In the first experiment, cells were then treated ( $n=3$ wells per treatment) with either $0 \mu \mathrm{mol} / \mathrm{L}, 200 \mu \mathrm{mol} / \mathrm{L}$ (physiological), or $800 \mu \mathrm{mol} / \mathrm{L}$ L-arginine (Sigma-Aldrich, St. Louis, $\mathrm{MO})$ in a serum-free environment. At two days posttreatment, cell proliferation was assessed for one plate of cells, and the media was replenished in the second plate of cells. Cell proliferation was then assessed in the second plate 4 days after the initial treatment. In the second experiment, cells were treated with $0 \mu \mathrm{mol} / \mathrm{L}, 200 \mu \mathrm{mol} /$ $\mathrm{L}$, or $800 \mu \mathrm{mol} / \mathrm{L} \mathrm{L}$-arginine with or without $\mathrm{N}$-omega -hydroxy-nor-arginine (Nor-NOHA; Calbiochem-EMD4 Biosciences, Billerica, MA), a polyamine synthesis inhibitor, in a serum-free environment. The media was replenished on day 2 post-treatment, and cell proliferation was assessed on day 4 post-treatment. Additionally, a third experiment examined the role of $\mathrm{NO}$ biosynthesis in endometrial RL95-2 cell proliferation: cells were treated with either $0 \mu \mathrm{mol} / \mathrm{L}, 200 \mu \mathrm{mol} / \mathrm{L}$, or $800 \mu \mathrm{mol} / \mathrm{L} \mathrm{L}$-arginine with or without 7 -Nitroindazole (7-NI), a NOS inhibitor, in a serum-free environment. 7NI was dissolved in ethanol, and all cells not exposed to 7-NI received an equal amount of ethanol. Cell proliferation was assessed according to procedures previously described by Kueng et al. [37]. Briefly, cells were washed in Dulbecco/s PBS (DPBS) and fixed in 3\% glutaraldehyde for $15 \mathrm{~min}$. Fixed cells were washed three times by submersion in de-ionized water and air dried, after which they were stained with crystal violet $(0.1 \%$ in $20 \%$ methanol) for $20 \mathrm{~min}$, followed by three washes with de-ionized water. Crystal violet was eluted using $10 \%$ glacial acetic acid, and the optical density was measured at $590 \mathrm{~nm}$. All experiments were repeated independently three times.

\section{Detection of DNA fragmentation}

RL95-2 cells were transferred to chamber slides $(100,000$ cells per chamber) in growth media for a period of $24 \mathrm{~h}$, after which they were serum and L-arginine starved for an additional 24 hours in an L-arginine free media (RPMI-1640 SILAC). Cells were then treated $(n=1$ chamber per treatment) with either $0 \mu \mathrm{mol} / \mathrm{L}, 200$ $\mu \mathrm{mol} / \mathrm{L}$, or $800 \mu \mathrm{mol} / \mathrm{L} \mathrm{L}$-arginine in a serum-free environment for 24 hours. Cells were washed with DPBS and fixed in a solution of $4 \%$ paraformaldehyde in PBS for 60 min, washed with DPBS, and incubated with a 
permeabilization solution $(0.1 \%$ Triton $\mathrm{X}-100$ in $0.1 \%$ sodium citrate) for $2 \mathrm{~min}$ on ice followed by two washes with DPBS. DNA fragmentation was detected by incubating cells with a FITC-labeled terminal deoxynucleotidyl transferase dUTP nick end labeling (TUNEL) solution (Roche Applied Science, Indianapolis, IN) at $37^{\circ} \mathrm{C}$ in a humidified incubator. After $60 \mathrm{~min}$, cells were washed three times with DPBS, the nucleus was counter-stained with DAPI (Santa Cruz Biotechnology, Santa Cruz, CA), and the slides where covered with a coverslip. TUNEL (ex. 490/20; em. 528/30) and DAPI (ex. 350/50; em. 457/50) staining were assessed using a Nikon Eclipse TE 2000-U fluorescence microscope. Three frames per chamber were acquired, and the proportion of cells that were TUNEL positive was counted. The entire experiment was repeated three independent times.

\section{Assessment of mitochondrial membrane potential $(\Delta \Psi \mathrm{m})$} RL95- 2 cells were seeded into 12-well plates $(750,000$ cells per well) and grown for 24 hours in growth media at which time they were serum and L-arginine starved for an additional 24 hours. Cells were then treated ( $n=3$ wells per treatment) with either $0 \mu \mathrm{mol} / \mathrm{L}, 200 \mu \mathrm{mol} / \mathrm{L}$, or 800 $\mu \mathrm{mol} / \mathrm{L} \mathrm{L}$-arginine in a serum-free environment for 24 hours, followed by incubation with $5,5^{\prime}, 6,6^{\prime}$-tetrachloro1,1',3,3'-tetraethylbenzimidazole-carbocyanide iodine (JC1; Cayman Chemical, Ann Arbor, MI) for 30 minutes at $37^{\circ} \mathrm{C}$. Loss of $\Delta \Psi \mathrm{m}$ was determined using fluorescence microscopy (Nikon Eclipse TE 2000-U) and flow cytometry (Becton Dickinson FACSCalibur). Immediately, following incubation with $\mathrm{JC}-1$, fluorescence microscopy was performed using a $490 \mathrm{~nm}$ excitation filter, with an orange emission indicating healthy $\Delta \Psi \mathrm{m}$ which is due to a potential-dependent aggregation of $\mathrm{JC}-1$ molecules in the mitochondria. In contrast, a loss of $\Delta \Psi \mathrm{m}$ results in the monomeric form of JC-1 in the cytosol which produces a green emission. For quantification, JC-1 labeled cells were harvested using EDTA (0.02\% in PBS) and analyzed by flow cytometry (3,000 cells per sample). Excitation was achieved with a $488 \mathrm{~nm}$ argon laser, and emission fluorescence was measured in the FL-1 (530/30 nm) and FL-2 $(585 / 42 \mathrm{~nm})$ channels to determine the proportion of cells with JC-1 monomers or JC-1 aggregates, respectively. From this analysis, the ratio of cells with JC-aggregates compared to cells with JC-1 monomers was determined. Flow cytometry analysis was repeated three independent times, and fluorescence microscopy was performed once to obtain representative images.

\section{Reverse transcriptase real time PCR}

RL95-2 cells were transferred to culture dishes $\left(1.0 \times 10^{6}\right.$ cells per dish) in growth media for a period of $24 \mathrm{~h}$ after which they were serum and L-arginine starved for an additional 24 hours in an L-arginine free media (RPMI1640 SILAC). Cells were then treated ( $\mathrm{n}=3$ culture dishes per treatment) with either $0 \mu \mathrm{mol} / \mathrm{L}, 200 \mu \mathrm{mol} / \mathrm{L}$, or 800 $\mu \mathrm{mol} / \mathrm{L} \mathrm{L}$-arginine in a serum-free environment. After 24 hours, cells were washed in cold DPBS, trypsinized, and stored as pellets at $-80^{\circ} \mathrm{C}$. Total RNA was isolated (High Pure RNA Isolation kit; Roche Applied Science, Indianapolis, IN), quantified (Nanodrop 1000; Thermo Scientific, Wilminton, DE), and reverse transcribed into cDNA (Transcriptor First Strand cDNA Synthesis; Roche Applied Science, Indianapolis, IN) using $500 \mathrm{ng}$ of total RNA.

For gene expression analysis, NCBI Primer BLAST was used to design primers for BAX, BCL2, and 18s rRNA (Table 1). Real-time PCR (Stratagene MX3005P; Agilent Technologies, Inc, Santa Clara, CA) was performed using $0.5 \mu \mathrm{L}$ of cDNA, a final concentration of $0.5 \mu \mathrm{M}$ of each primer, and SYBR Green I Master Mix (Roche Applied Science, Indianapolis, IN). The PCR conditions were the following: $5 \mathrm{~min}$ at $95^{\circ} \mathrm{C}$; 40 cycles of $30 \mathrm{sec}$ at $95^{\circ} \mathrm{C} ; 30 \mathrm{sec}$ at the optimal annealing temperature (Table 1); $30 \mathrm{sec}$ at $72^{\circ} \mathrm{C}$. Relative gene expression was calculated using the $2^{-\Delta \Delta C T}$ method [38]. The entire experiment was repeated three independent times.

\section{In cell ELISA and Western-immunoblot detection of BCL2, $B A X, B A D$, and $p-B A D$ proteins}

In a 96-well plate, RL95-2 cells were cultured $(80,000$ cells per well) in growth media for a period of $24 \mathrm{~h}$, after which they were serum and L-arginine starved for an additional 24 hours in an L-arginine free media (RPMI1640 SILAC). Cells were then treated $(n=3$ wells per treatment) with either $0 \mu \mathrm{mol} / \mathrm{L}, 200 \mu \mathrm{mol} / \mathrm{L}$, or 800 $\mu \mathrm{mol} / \mathrm{L} \mathrm{L}$-arginine in a serum-free environment. After 24 hours, cells were fixed with paraformaldehyde (4\% in PBS). BCL2, BAX, BAD, and p-BAD expression was assessed using the Pierce Colormetric In-Cell ELISA kit (Thermo Scientific, Waltham, MA) as per the manufacturer's instructions. BCL2, BAX, BAD, and pBAD measurements were obtained and normalized to cell number using the Janus Green Whole-Cell stain supplied with the kit. The entire experiment was isolated from frozen-thawed RL95-2 cells using complete RIPA buffer (Santa Cruz Biotech Inc, Santa Cruz, CA). Isolated protein was resolved onto an SDS PAGE gel and transferred to a PVDF membrane. The WesternBreeze Chromogenic kit was utilized for immunodection as per the manufacturer's instructions (Life Technologies, Inc. Grand Island, NY). Primary antibody concentration for western-immunoblotting were the following: BCL2: 0.004 $\mu \mathrm{g} / \mu \mathrm{L}$; BAX: $0.004 \mu \mathrm{g} / \mu \mathrm{L} ; \mathrm{p}-\mathrm{BAD}: 0.008 \mu \mathrm{g} / \mu \mathrm{L}$; and BAD: $0.001 \mu \mathrm{g} / \mu \mathrm{L}$. BCL2 (sc-130307), BAD (sc-8044) and serine136 phosphorylated BAD (p-BAD; sc-12969) primary 
Table 1 Primer sequences and characteristics

\begin{tabular}{|c|c|c|c|c|}
\hline Gene & GenBank Acc. \# & Primer sequences $\left(5^{\prime}-3^{\prime}\right)$ & Annealing $\mathrm{T}\left({ }^{\circ} \mathrm{C}\right)$ & Amplicon size (bp) \\
\hline \multirow[t]{2}{*}{ BAX } & NM_004324.3 & S: TCTGACGGCAACTTCAACTG & 54.5 & 155 \\
\hline & & AS: TTGAGGAGTCTCACCCAACC & & \\
\hline \multirow[t]{2}{*}{$\mathrm{BCL} 2$} & NM_000633.2 & S: CGTCAACCGGGAGATGTCGCC & 62.0 & 132 \\
\hline & & AS: CTGGGGCCGTACAGTTCCACA & & \\
\hline \multirow[t]{2}{*}{ 18s rRNA } & X03205.1 & S: AAACGGCTACCACATCCAAG & 56.0 & 188 \\
\hline & & AS: CCTCCAATGGATCCTCGTTA & & \\
\hline
\end{tabular}

antibodies were obtained from Santa Cruz Biotechnolgy, Inc. BAX primary antibody (B3428) was obtained from Sigma-Aldrich, Inc.

\section{Statistical analysis}

The Shapiro-Wilk test was utilized to test the data for normal distribution. All data were normally distributed except for cell-proliferation and JC-1 data. Normally distributed data were analyzed using one-way or twoway ANOVA, when appropriate, followed by Fisher's LSD test for pairwise comparison. Data that tested to be non-parametric were analyzed by Friedman's one-way or two-way non-parametric ANOVA, when appropriate, followed by Tukey's HSD test for pairwise comparison. The threshold of significance was fixed at $\mathrm{P}<0.05$. Data are presented as least square means \pm standard error of the mean (SEM).

\section{Results}

Effect of L-arginine on endometrial RL95-2 cell proliferation

The presence of L-arginine at physiological $(200 \mu \mathrm{mol} / \mathrm{L})$ and supraphysiological $(800 \mu \mathrm{mol} / \mathrm{L})$ concentrations increased $(\mathrm{P}<0.05)$ endometrial RL95-2 cell proliferation at days 2 and 4 post-treatment with proliferation being increased by approximately 4-fold on day 4 (Figure 1A). Additionally, a dose dependent effect of L-arginine on endometrial RL95-2 cell proliferation was observed on day 2 post-treatment at which time cell proliferation was

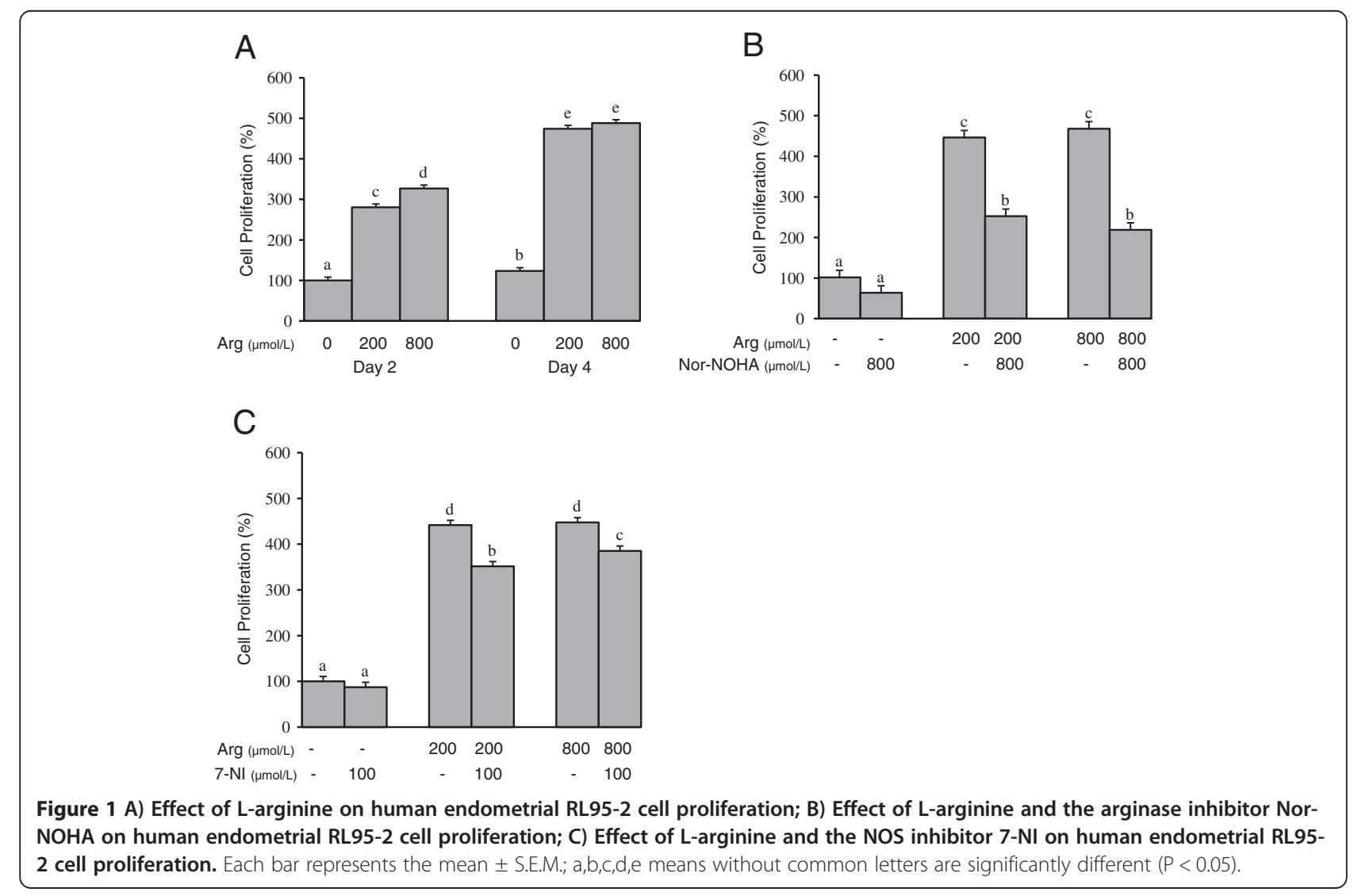


greater $(\mathrm{P}<0.05)$ for cells treated with $800 \mu \mathrm{mol} / \mathrm{L} \mathrm{L}$ arginine compared to those exposed to $200 \mu \mathrm{mol} / \mathrm{L}$.

\section{Inhibitory Effect of nor-NOHA on endometrial RL95-2 cell proliferation}

To test whether polyamines, L-arginine metabolites, are responsible for L-arginine's effect on cell proliferation, cells were exposed to L-arginine and the arginase inhibitor nor-NOHA. As in experiment one, the addition of L-arginine $(200 \mu \mathrm{mol} / \mathrm{L}$ and $800 \mu \mathrm{mol} / \mathrm{L})$ increased $(\mathrm{P}<0.05)$ endometrial RL95-2 cell proliferation, but this effect was reduced 2 -fold $(\mathrm{P}<0.05)$ with the addition of $800 \mu \mathrm{mol} / \mathrm{L}$ nor-NOHA (Figure 1B).

\section{Inhibitory effect of 7-NI on endometrial RL95-2 cell proliferation}

Cells were exposed to L-arginine and the NOS inhibitor 7-NI to determine if L-arginine enhances endometrial RL95-2 cell proliferation through NO biosynthesis. Again, L-arginine $(200 \mu \mathrm{mol} / \mathrm{L}$ and $800 \mu \mathrm{mol} / \mathrm{L})$ increased
$(\mathrm{P}<0.05)$ endometrial RL95-2 cell proliferation, and this effect on cell proliferation was reduced $(\mathrm{P}<0.05)$ with the addition of $100 \mu \mathrm{mol} / \mathrm{L}$ of 7 -NI (Figure 1C).

\section{Effect of L-arginine on endometrial RL95-2 cell apoptosis}

Because of the inverse relationship that exists between cell proliferation and apoptosis [39], we sought to determine if L-arginine's positive effect on cell proliferation was associated with a concomitant decrease in apoptosis. The addition of L-arginine $(200 \mu \mathrm{mol} / \mathrm{L}$ and $800 \mu \mathrm{mol} / \mathrm{L})$ decreased $(\mathrm{P}<0.05)$ the proportion of cells that stained positive for TUNEL by approximately 13 -fold, indicating a reduction in DNA fragmentation and, thus, apoptosis in the presence of L-arginine (Figure 2A-D).

\section{Effect of L-arginine on mitochondiral membrane potential $\left(\Delta \Psi_{\mathrm{m}}\right)$}

Fluorescence microscopy analysis of JC-1 stained endometrial RL95-2 cells revealed that the presence of Larginine $(200 \mu \mathrm{mol} / \mathrm{L}$ and $800 \mu \mathrm{mol} / \mathrm{L})$ increased the
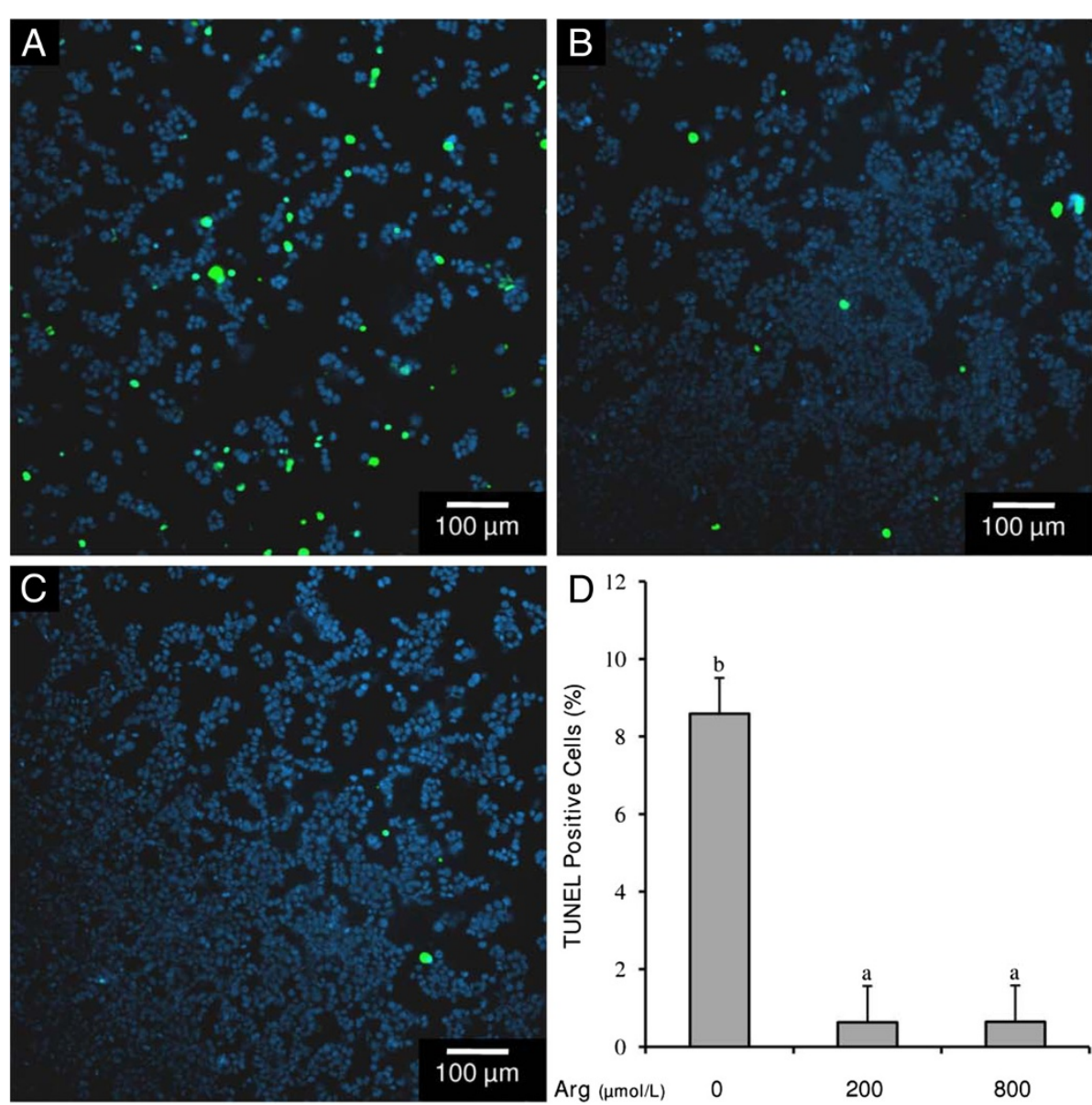

Figure 2 Effect of L-arginine on human endometrial RL95-2 cell apoptosis as assessed by TUNEL assay and fluorescent microscopy. Representative micrographs of cells exposed to (A) $0 \mu \mathrm{mol} / \mathrm{L}$, (B) $200 \mu \mathrm{mol} / \mathrm{L}$, or (C) $800 \mu \mathrm{mol} / \mathrm{L} \mathrm{L}$-arginine. Cells staining green are TUNEL positive cells experiencing DNA fragmentation. (D) Percentage of cells staining positive for TUNEL after exposure to either $0 \mu \mathrm{mol} / \mathrm{L}, 200 \mu \mathrm{mol} / \mathrm{L}$, $800 \mu \mathrm{mol} / \mathrm{L} \mathrm{L}$-arginine. Each bar represents the mean \pm S.E.M.; a,b means without common letters are significantly different $(P<0.05)$. 
proportion of cells with healthy $\Delta \Psi \mathrm{m}$, as indicated by more cells yielding an orange emission upon excitation (Figure 3A-C). Furthermore, flow cytometry revealed that the addition of L-arginine to the culture media increased $(\mathrm{P}<0.05)$ the ratio of cells with $\mathrm{JC}-1$ aggregates compared to cells with JC-1 monomers by approximately 2.5 -fold (Figure 3D), indicating that L-arginine reduces mitochondrial membrane potential disruption in endometrial RL95-2 cells.

\section{Effect of L-arginine on BAX and BCL2 gene and protein expression}

The presence of L-arginine at physiological $(200 \mu \mathrm{mol} /$ $\mathrm{L})$ and supraphysiological $(800 \mu \mathrm{mol} / \mathrm{L})$ concentrations dose-dependently reduced $(\mathrm{P}<0.05)$ the amount of $B A X$ mRNA expression, with endometrial RL95-2 cells exposed to $800 \mu \mathrm{mol} / \mathrm{L} \mathrm{L}$-arginine expressing the least $(\mathrm{P}<0.05)$ amount of $B A X$ mRNA (Figure $4 \mathrm{~A})$. Interestingly, cells exposed to L-arginine also expressed less
$(\mathrm{P}<0.05)$ BCL2 mRNA, and had a lower $(\mathrm{P}<0.05) B C L 2$ to $B A X$ mRNA ratio (Figure $4 \mathrm{~B}$ and $\mathrm{C}$ ). Exposure to $\mathrm{L}$ arginine resulted in a $B C L 2$ to $B A X$ mRNA ratio of approximately one, while cells not exposed to L-arginine exhibited a ratio of two. L-arginine at physiological $(200 \mu \mathrm{mol} / \mathrm{L})$ and supraphysiological $(800 \mu \mathrm{mol} / \mathrm{L})$ concentrations had no effect on BAX protein expression (Figure 4D); however, in cells that were not exposed to L-arginine, BCL2 protein levels were elevated $(\mathrm{P}<0.05 ;$ Figure $4 \mathrm{E})$. Additionally, cells exposed to L-arginine had a lower $(\mathrm{P}<0.05)$ BCL2 to BAX protein ratio compared to cells not exposed to L-arginine (Figure 4F).

\section{Effect of L-arginine on phosphorylation of BAD protein}

Because L-arginine did not increase the BCL2 to BAX mRNA and protein ratio, an alternate mechanism for Larginine's promotion of cell survival and prevention of apoptosis was investigated. To this end, endometrial
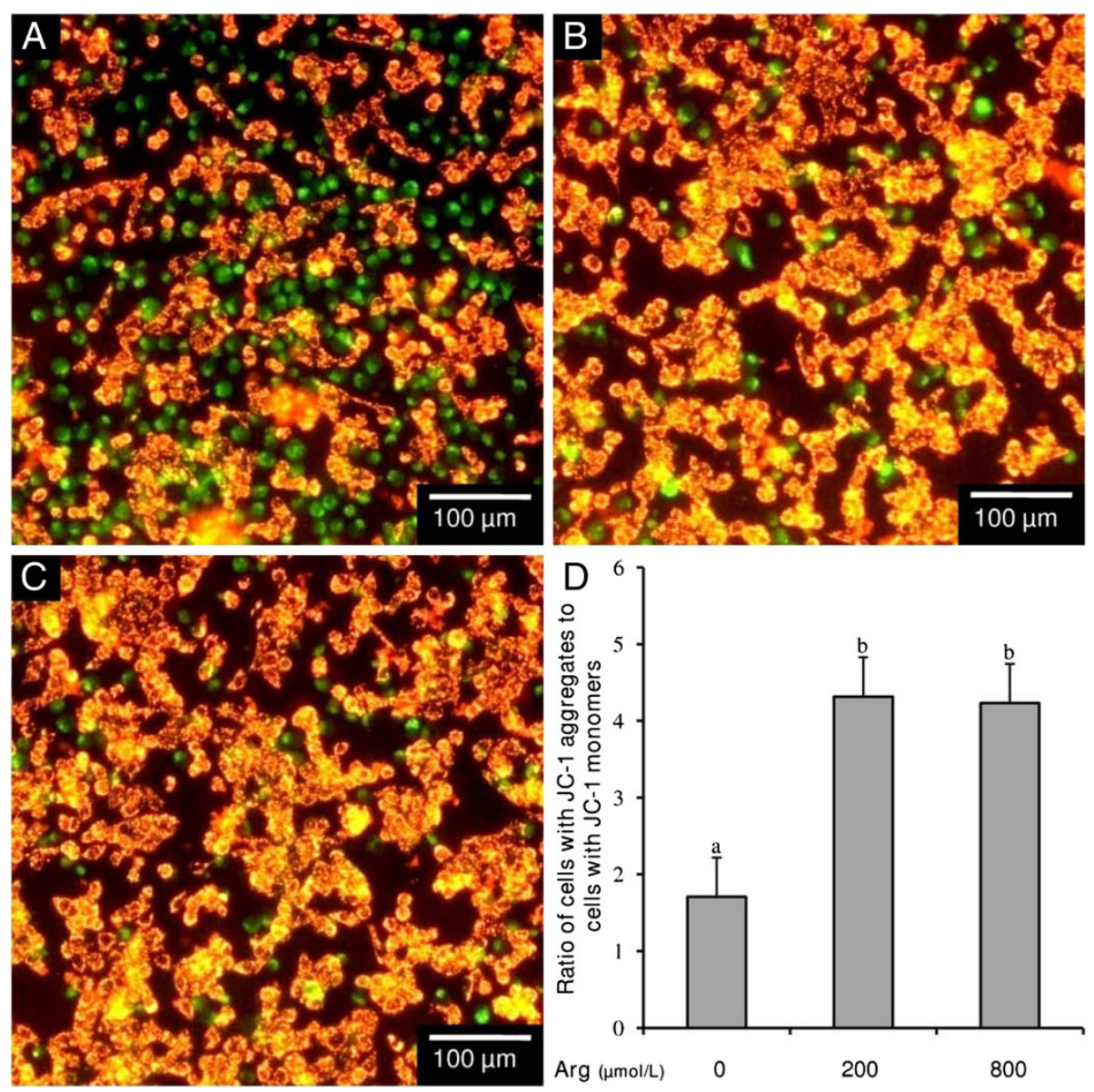

Figure 3 Effect of L-arginine on human endometrial RL95-2 cell mitochondrial membrane potential $(\Delta \Psi \mathrm{m})$ as assessed by JC-1 staining. Representative micrographs of cells exposed to (A) $0 \mu \mathrm{mol} / \mathrm{L}$, (B) $200 \mu \mathrm{mol} / \mathrm{L}$, or (C) $800 \mu \mathrm{mol} / \mathrm{L}$ L-arginine. Cells staining green (JC-1 monomers) are cells with a disrupted $\Delta \psi \mathrm{m}$, while cells staining orange (JC-1 aggregates) have a healthy $\Delta \psi \mathrm{m}$. (D) Ratio of cells with JC-1 aggregates to cells with JC-1 monomers as assessed by flow cytometry. Each bar represents the mean \pm S.E.M.; a,b means without common letters are significantly different $(P<0.05)$. 


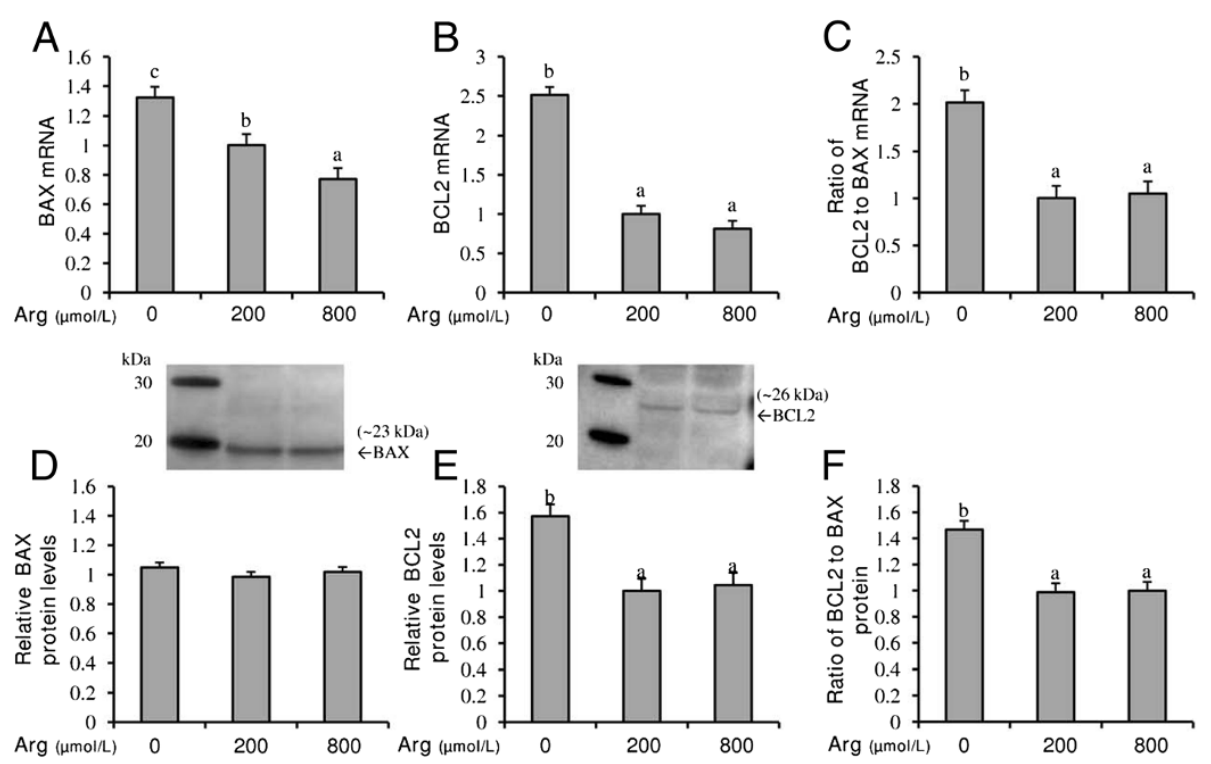

Figure 4 Effect of L-arginine on (A) BAX mRNA, (B) BCL2 mRNA, (C) ratio of BCL2 to BAX mRNA, (D) BAX protein, (E) BCL2 protein, and (F) the ratio of $B C L 2$ to $B A X$ protein in human endometrial RL95-2 cells. Western-immunoblotting of RL95-2 total cell protein for BAX (D) and BCL2 (E) yielded proteins of approximately $23 \mathrm{kDa}$ and $26 \mathrm{kDa}$, respectively. Each bar represents the mean \pm S.E.M.; a,b means without common letters are significantly different $(P<0.05)$.

RL95-2 cells were exposed to 0,200 , or $800 \mu \mathrm{mol} / \mathrm{L}$ of Larginine to determine total and phosphorylated forms of $\mathrm{BAD}$, which is a promoter of mitochondrial mediated apoptosis when not phosphorylated [40]. L-arginine at 200 and $800 \mu \mathrm{mol} / \mathrm{L}$ did not affect the relative levels of total BAD protein in RL95-2 cells (Figure 5A). However, the addition of L-arginine did increase $(\mathrm{P}<0.05)$ the relative levels of phosphorylated (Ser-136) BAD protein and, thus, the ratio of phosphorylated $\mathrm{BAD}$ protein to total $\mathrm{BAD}$ protein in endometrial RL95-2 cells (Figure 5B and C).

\section{Discussion}

L-arginine is a versatile amino acid, serving as a precursor for many molecules including $\mathrm{NO}$ and polyamines
[4]. The plasma concentration of L-arginine has been reported to be around $200 \mu \mathrm{mol} / \mathrm{L}$ in humans during the fed state $[4,41]$. Therefore, we sought to determine the effect of L-arginine on endometrial RL95-2 cells at physiological $(200 \mu \mathrm{mol} / \mathrm{L})$ and supraphysiological $(800 \mu \mathrm{mol} / \mathrm{L})$ concentrations. The presence of NOS and/or arginase enzymes in the endometrium of many species indicates the ability of the endometrium to catabolize L-arginine [20,23-28]. In females, $\mathrm{NO}$ is produced in the endometrium [42] and is involved in embryo implantation and development [43-45]. Polyamines are also produced by the endometrium $[46,47]$ and have been shown to be important for embryo implantation, as inhibition of

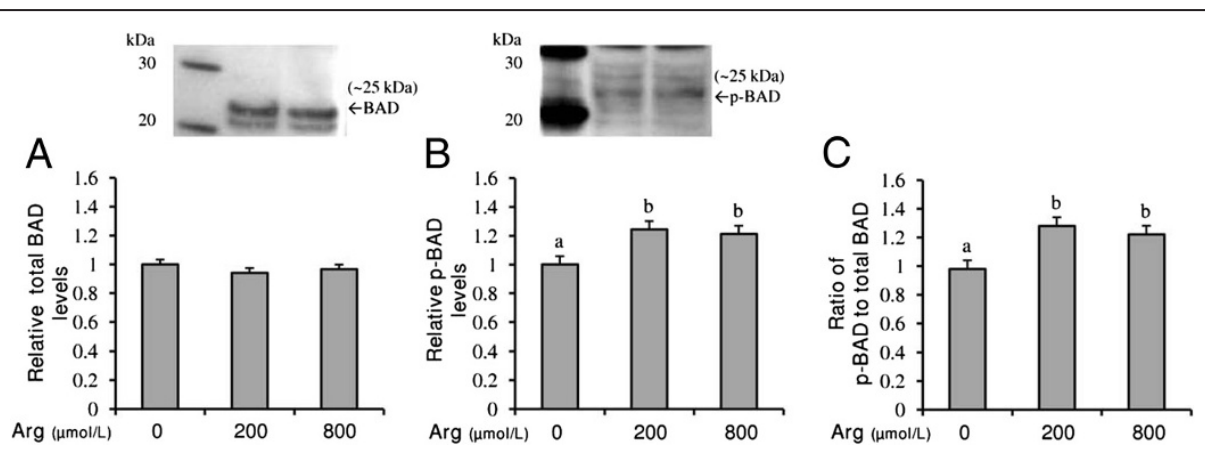

Figure 5 Effect of L-arginine on (A) total BAD protein, $(B)$ phosphorylated BAD ( $p-B A D)$ protein, and $(C)$ the ratio of p-BAD protein to total BAD protein in human endometrial RL95-2 cells. Western-immunoblotting of RL95-2 total cell protein for BAD (A) and p-BAD (B) yielded proteins of approximately $25 \mathrm{kDa}$. Each bar represents the mean \pm S.E.M.; a,b means without common letters are significantly different $(P<0.05)$. 
polyamine synthesis reduced pregnancy rates in mice [46].

L-arginine has been reported to be present in the uterine flushes of sheep [48], cows [49], rats [50], and humans [29], with concentrations in human uterine flushes ranging from $220 \mu \mathrm{mol} / \mathrm{L}$ to $330 \mu \mathrm{mol} / \mathrm{L}$ depending upon the phase of the menstrual cycle [29]. Additional work has revealed that mRNA of the Larginine transporters SLC7A1, SLC7A2, and SLC7A3 are present in ovine uterine luminal epithelial [51]. Furthermore, the positive influence that L-argnine has on cell signaling, proliferation, hypertrophy, hyperplasia, and migration of ovine trophectoderm cells $[9,17]$ suggests that L-arginine is transported into the uterine lumen to support growth and development of the periimplantation embryo.

In addition to supporting the peri-implantation embryo, L-arginine may also have a direct effect on the uterine luminal epithelium. Proliferation of the endometrium has been implicated as a vital process which provides an optimal environment for embryo adhesion and implantation [52], and this argument is further supported by the observation that increasing endometrial thickness is associated with improved implantation rates in humans [53-55]. Interestingly, the uterine lumen concentration of $\mathrm{L}$-arginine is greatest during the proliferative phase of the menstrual cycle [29], suggesting that L-arginine may have a role in the proliferation of the endometrial epithelium which must regenerate following menstruation. L-arginine and its metabolites, $\mathrm{NO}$ and polyamines, have a dual role in cell proliferation and apoptosis. In some cell types, Larginine, $\mathrm{NO}$, and polyamines stimulate cell proliferation and reduce apoptosis $[8,9,56,57]$, yet they inhibit cell proliferation and promote apoptosis in others [58-61]. Results from the current study indicate that L-argrinine enhances endometrial RL95-2 cell proliferation at physiological and supraphysiological concentrations. Moreover, Nor-NOHA, an arginase inhibitor, and 7-NI, an NOS inhibitor, reduced the positive effect that Larginine had on endometrial RL95-2 cell proliferation. Conversion of L-arginine to ornithine, via arginase, is the first enzymatic process involved in polyamine synthesis [4]. Likewise, NOS is responsible for converting Larginine to NO [4]. Together, the inhibitory effect that Nor-NOHA and 7-NI exhibited in the presence of Larginine indicates that $\mathrm{L}$-arginine enhances endometrial RL95-2 cell proliferation through polyamine and NO mediated pathways, which both have a positive influence on cell proliferation [5-11].

Cell proliferation is often inversely related to apoptosis [39,62-64], and a reduction in apoptosis is a contributing factor in the enhancement of cell proliferation [65]. Therefore, we hypothesized that the enhancement of cell proliferation in the presence of L-arginine would be associated with decreased endometrial RL95-2 cell apoptosis. Apoptosis in the endometrium is a key feature of the human menstrual cycle and aids in maintaining endometrial homeostasis by eliminating cells from the functionalis layer during the late secretory phase [66]. In the functionalis layer of the endometrium, apoptosis exhibits a cyclic pattern with the least amount being observed during the proliferative phase followed by an increase during the secretory phase and the maximum being observed during menstruation $[67,68]$. The exposure of endometrial RL95-2 cells to physiological and supraphysiological concentrations of L-arginine reduced the proportion of cells that exhibited DNA fragmentation as assessed by TUNEL assay. Activation of endonucleases [69] and the subsequent DNA fragmentation [70] are considered to be hallmark characteristics of cells undergoing apoptosis. To this end, the current results demonstrate that the presence of $\mathrm{L}$-arginine reduces the proportion of endometrial RL95-2 cells experiencing apoptosis. Apoptosis can occur through either receptor-ligand mediated pathways or mitochondrial mediated pathways, with both resulting in DNA fragmentation [71]. Receptor-ligand mediated apoptosis requires an external signal, while mitochondrial mediated apoptosis occurs through the disruption of the mitochondrial membrane [71]. As the presence or absence of L-arginine would represent an intracellular event rather than receptor mediated extracellular signaling, we hypothesized that L-arginine's prevention of apoptosis in endometrial RL95-2 cells is mediated through the mitochondria. The presence of L-arginine in the culture media increased the ratio of cells with a healthy mitochondrial membrane compared to cells with an altered mitochondrial membrane potential. Thus, the current study indicates that L-arginine reduces the incidence of endometrial RL95-2 cell apoptosis by preventing the disruption of mitochondrial membrane potential, suggesting a role for L-arginine in the regulation of endometrial epithelial apoptosis.

Mitochondrial membrane potential is highly influenced by proteins that belong to the BCL2 family [72]. The proapoptotic protein BAX and the anti-apoptotic protein BCL2 are often studied together as indicators of apoptosis. In healthy cells, a balance exists in which BCL2 is normally found imbedded in the mitochondrial membrane [73]. Under apoptotic conditions, activated BAX will embed in the mitochondrial membrane with BCL2 and disrupt the mitochondrial membrane potential [73]. Accordingly, we examined if L-arginine's prevention of apoptosis is through a BCL2 and BAX mediated event. Interestingly, the presence of L-arginine did not increase the ratio of BCL2 to BAX in endometrial RL95-2 cells. In fact, the BCL2 to BAX mRNA and protein ratios were higher in endometrial 
RL95-2 cells not exposed to L-arginine which were undergoing apoptosis through a mitochondrial mediated pathway. Despite the anti-apoptotic properties of BCL2, upregulation of BCL2 mRNA and protein has been reported in cells undergoing apoptosis [74]. Moreover, increased expression of BCL2 protein can lead to disruption of mitochondrial membrane potential [75], as caspases can cleave BCL2 into a BAX-like molecule which can serve as a latent pro-apoptotic stimuli in apoptotic cells [76].

Because exposure to L-arginine did not increase the ratio of $\mathrm{BCL} 2$ to $\mathrm{BAX}$, we hypothesized that $\mathrm{L}$-arginine might decrease endometrial RL95-2 cell apoptosis through an alternative mechanism. In addition to BCL2 and BAX, BAD is another member of the BCL2 family of proteins that affects mitochondrial membrane potential. The presence of $\mathrm{L}$-arginine in the culture media did not affect the levels of total BAD. However, L-arginine increased p-BAD (Ser-136) levels in endometrial RL95-2 cells and increased the ratio of p-BAD to BAD, indicating that L-arginine enhances the phosphorylation of BAD protein at serine residue 136 in endometrial RL952 cells. When BAD is phosphorylated at either serine residue 112 (Ser-112) or 136 (Ser-136), it is bound by 14-3-3 and sequestered in the cytosol [40]. In contrast, non-phosphorylated BAD interacts with BCL2 and BCL$\mathrm{XL}$ embedded in the mitochondrial membrane and inhibits their anti-apoptotic properties [77,78] and causes release of cytochrome $\mathrm{C}$ [79]. In this regard, L-arginine reduces mitochondrial membrane disruption and, thus, apoptosis through phosphorylation of BAD in endometrial RL95-2 cells. BAD protein is phosphorylated at serine residue 136 through the kinase activity of PI3K-dependent Akt-1 [80]. L-arginine increases phosphorylation, and therefore the activity, of Akt- 1 in ovine trophectoderm cells [17]. Moreover, NO can stimulate phosphorylation of Akt-1 [14-16], and Akt-1 phosphorylation is also enhanced in cells with elevated expression of ornithine decarboxylase [81], the enzyme responsible for converting ornithine to first polyamine putrescine. Thus, it is likely that the presence of L-arginine in the culture media increased p-BAD levels in endometrial RL95-2 cells by influencing Akt-1 phosphorylation through the action of polyamines and/or NO.

\section{Conclusions}

In summary, L-arginine added to the culture media at physiological $(200 \mu \mathrm{mol} / \mathrm{L})$ and supraphysiological concentrations $(800 \mu \mathrm{mol} / \mathrm{L})$ enhanced endometrial RL95-2 cell proliferation through mechanisms mediated by $\mathrm{NO}$ and polyamine biosynthesis and by reducing endometrial RL95-2 cell apoptosis through the phosphorylation of BAD protein. Cell proliferation is an important process in the human endometrium, as the endometrial epithelium must regenerate following the losses experienced during menstruation in preparation for the attachment and implantation of a potential embryo. Accordingly, the findings of the present study demonstrate a role for L-arginine in the regulation of endometrial growth and apoptosis. Moreover, a supraphysiological concentration of $\mathrm{L}$-arginine had no negative effects on the parameters measured, revealing a possible beneficial effect of dietary L-arginine supplementation on endometrial growth.

\section{Competing interests}

The authors declare that they have no competing interests.

\section{Authors' contributions}

JMG, JMF, and PLR conceived the study and participated in the design of the study. JMG, JMF, KEP, JVS, and SDB performed the experiments. JMG conducted the statistical analysis. JMG, JMF, and PLR interpreted the data and JMG drafted the manuscript. All authors read and approved the final manuscript.

\section{Acknowledgements}

This research was supported by the USDA-ARS Special Initiative No. 58-6402 $-3-0120$.

\section{Author details}

'Department of Pathobiology and Population Medicine, Mississippi State University, Mississippi State, MS, USA. ${ }^{2}$ Department of Animal and Dairy Sciences, Mississippi State University, Mississippi State, MS, USA. ${ }^{3}$ Facility for Organismal and Cellular Imaging, Mississippi State University, Mississippi State, Mississippi, USA. ${ }^{4}$ Department of Basic Sciences, Mississippi State University, Mississippi State, Mississippi, USA.

Received: 16 December 2012 Accepted: 24 February 2013 Published: 26 February 2013

\section{References}

1. Flynn NE, Meininger CJ, Haynes TE, WU G: The metabolic basis of arginine nutrition and pharmacotherapy. Biomed Pharmacother 2002, 56:427-438.

2. Shao A, Hathcock JN: Risk assessment for the amino acids taurine, l-glutamine and l-arginine. Regul Toxicol Pharmacol 2008, 50:376-399.

3. Visek WJ: Arginine Needs, Physiological State and Usual Diets. A Reevaluation. J Nutr 1986, 116:36-46.

4. $\mathrm{Wu} \mathrm{G}$, Morris SM Jr: Arginine metabolism: nitric oxide and beyond. Biochem J 1998, 336(Pt 1):1-17.

5. Hu X, Washington S, Verderame MF, Manni A: Interaction between Polyamines and the Mitogen-Activated Protein Kinase Pathway in the Regulation of Cell Cycle Variables in Breast Cancer Cells. Cancer Res 2005, 65:11026-11033.

6. Ray RM, McCormack SA, Johnson LR: Polyamine depletion arrests growth of IEC- 6 and Caco-2 cells by different mechanisms. Am J Physiol Gastrointest Liver Physiol 2001, 281:G37-G43.

7. Ray RM, Zimmerman BJ, McCormack SA, Patel TB, Johnson LR: Polyamine depletion arrests cell cycle and induces inhibitors p21Waf1/Cip1, p27Kip1, and p53 in IEC-6 cells. Am J Physiol Gastrointest Cell Physiol 1999, 276:C684-C691.

8. Ziche M, Morbidelli L, Masini E, Amerini S, Granger HJ, Maggi CA, Geppetti $P$, Ledda F: Nitric oxide mediates angiogenesis in vivo and endothelial cell growth and migration in vitro promoted by substance P. J Clin Invest 1994, 94:2036-2044.

9. Kim JY, Burghardt RC, Wu G, Johnson GA, Spencer TE, Bazer FW: Select nutrients in the ovine uterine lumen. VIII. Arginine stimulates proliferation of ovine trophectoderm cells through MTOR-RPS6K-RPS6 signaling cascade and synthesis of nitric oxide and polyamines. Biol Reprod 2011, 84:70-78.

10. Vasa M, Breitschopf K, Zeiher AM, Dimmeler S: Nitric Oxide Activates Telomerase and Delays Endothelial Cell Senescence. Circ Res 2000, 87:540-542.

11. Zheng M, Ekmekcioglu S, Walch ET, Tang C-H, Grimm EA: Inhibition of nuclear factor-[kappa]B and nitric oxide by curcumin induces G2/M cell cycle arrest and apoptosis in human melanoma cells. Melanoma Res 2004, 14:165-171.

12. Igarashi K, Kashiwagi K: Polyamines: mysterious modulators of cellular functions. Biochem Biophys Res Commun 2000, 271:559-564. 
13. Seiler N, Raul F: Polyamines and apoptosis. J Cell Mol Med 2005, 9:623-642.

14. Kawasaki K, Smith RS, Hsieh C-M, Sun J, Chao J, Liao JK: Activation of the Phosphatidylinositol 3-Kinase/Protein Kinase Akt Pathway Mediates Nitric Oxide-Induced Endothelial Cell Migration and Angiogenesis. Mol Cell Biol 2003, 23:5726-5737.

15. Bazer FW, Song G, Kim J, Erikson DW, Johnson GA, Burghardt RC, Gao H, Carey Satterfield M, Spencer TE, Wu G: Mechanistic mammalian target of rapamycin (MTOR) cell signaling: Effects of select nutrients and secreted phosphoprotein 1 on development of mammalian conceptuses. Mol Cell Endocrinol 2012, 354:22-33.

16. Fukumura D, Kashiwagi S, Jain RK: The role of nitric oxide in tumour progression. Nat Rev Cancer 2006, 6:521-534.

17. Kim J-Y, Burghardt RC, Wu G, Johnson GA, Spencer TE, Bazer FW: Select Nutrients in the Ovine Uterine Lumen. VII. Effects of Arginine, Leucine, Glutamine, and Glucose on Trophectoderm Cell Signaling, Proliferation, and Migration. Biol Reprod 2011, 84:62-69.

18. Kong X, Tan B, Yin Y, Gao H, Li X, Jaeger LA, Bazer FW, Wu G: I-Arginine stimulates the mTOR signaling pathway and protein synthesis in porcine trophectoderm cells. J Nutr Biochem 2012, 23:1178-1183.

19. Wu G, Bazer FW, Tuo W, Flynn SP: Unusual abundance of arginine and ornithine in porcine allantoic fluid. Biol Reprod 1996, 54:1261-1265.

20. Zeng X, Wang F, Fan X, Yang W, Zhou B, Li P, Yin Y, Wu G, Wang J: Dietary arginine supplementation during early pregnancy enhances embryonic survival in rats. J Nutr 2008, 138:1421-1425.

21. Mateo RD, Wu G, Bazer FW, Park JC, Shinzato I, Kim SW: Dietary L-arginine supplementation enhances the reproductive performance of gilts. J Nutr 2007, 137:652-656

22. Greene JM, Dunaway CW, Bowers SD, Rude BJ, Feugang JM, Ryan PL: Dietary L-arginine supplementation during gestation in mice enhances reproductive performance and Vegfr 2 transcription activity in the fetoplacental unit. J Nutr 2012, 142:456-460.

23. Massmann GA, Zhang J, Figueroa JP: Functional and molecular characterization of nitric oxide synthase in the endometrium and myometrium of pregnant sheep during the last third of gestation. Am J Obstet Gynecol 1999, 181:116-125.

24. Kwon H, Wu G, Bazer FW, Spencer TE: Developmental changes in polyamine levels and synthesis in the ovine conceptus. Biol Reprod 2003, 69:1626-1634

25. Kwon H, Wu G, Meininger CJ, Bazer FW, Spencer TE: Developmental changes in nitric oxide synthesis in the ovine placenta. Biol Reprod 2004, 70:679-686.

26. Wu G, Pond WG, Flynn SP, Ott TL, Bazer FW: Maternal dietary protein deficiency decreases nitric oxide synthase and ornithine decarboxylase activities in placenta and endometrium of pigs during early gestation. J Nutr 1998, 128:2395-2402.

27. Yu H, Yoo PK, Aguirre CC, Tsoa RW, Kern RM, Grody WW, Cederbaum SD, lyer RK: Widespread Expression of Arginase I in Mouse Tissues: Biochemical and Physiological Implications. J Histochem Cytochem 2003, 51:1151-1160.

28. Telfer JF, Irvine GA, Kohnen G, Campbell S, Cameron IT: Expression of endothelial and inducible nitric oxide synthase in non-pregnant and decidualized human endometrium. Mol Hum Reprod 1997, 3:69-75.

29. Casslen BG: Free amino acids in human uterine fluid. Possible role of high taurine concentration. J Reprod Med 1987, 32:181-184.

30. Wadehra M, Mainigi M, Morales SA, Rao RG, Gordon LK, Williams CJ, Braun J: Steroid hormone regulation of EMP2 expression and localization in the endometrium. Reprod Biol Endocrinol 2008, 6:15.

31. Horne AW, Lalani EN, Margara RA, White JO: The effects of sex steroid hormones and interleukin-1-beta on MUC1 expression in endometrial epithelial cell lines. Reproduction 2006, 131:733-742.

32. Thie M, Harrach-Ruprecht B, Sauer H, Fuchs P, Albers A, Denker HW: Cell adhesion to the apical pole of epithelium: a function of cell polarity. Eur J Cell Biol 1995, 66:180-191.

33. Rahnama F, Thompson B, Steiner M, Shafiei F, Lobie PE, Mitchell MD Epigenetic regulation of E-cadherin controls endometrial receptivity. Endocrinol 2009, 150:1466-1472.

34. Yang H, Lei C, Cheng C, Feng Y, Zhang W, Petracco RG, Sak S: The antiapoptotic effect of galectin-3 in human endometrial cells under the regulation of estrogen and progesterone. Biol Reprod 2012, 87:39.

35. Tinel H, Denker HW, Thie M: Calcium influx in human uterine epithelial RL95-2 cells triggers adhesiveness for trophoblast-like cells. Model studies on signalling events during embryo implantation. Mol Hum Reprod 2000, 6:1119-1130.

36. Rohde LH, Carson DD: Heparin-like glycosaminoglycans participate in binding of a human trophoblastic cell line (JAR) to a human uterine epithelial cell line (RL95). J Cell Physiol 1993, 155:185-196.

37. Kueng W, Silber E, Eppenberger U: Quantification of cells cultured on 96-well plates. Anal Biochem 1989, 182:16-19.

38. Livak KJ, Schmittgen TD: Analysis of relative gene expression data using realtime quantitative PCR and the 2(-Delta Delta C(T)) Method. Methods 2001, 25:402-408.

39. Ambrosini G, Adida C, Sirugo G, Altieri DC: Induction of apoptosis and inhibition of cell proliferation by survivin gene targeting. J Biol Chem 1998, 273:11177-11182.

40. Zha J, Harada H, Yang E, Jockel J, Korsmeyer SJ: Serine phosphorylation of death agonist $B A D$ in response to survival factor results in binding to 14-3-3 not BCL-X(L). Cell 1996, 87:619-628.

41. Castillo L, Chapman TE, Sanchez M, Yu YM, Burke JF, Ajami AM, Vogt J, Young VR: Plasma arginine and citrulline kinetics in adults given adequate and arginine-free diets. Proc Nat Acad Sci 1993, 90:7749-7753.

42. Cameron IT, Campbell S: Nitric oxide in the endometrium. Hum Reprod Update 1998, 4:565-569.

43. Purcell TL, Given R, Chwalisz K, Garfield RE: Nitric oxide synthase distribution during implantation in the mouse. Mol Hum Reprod 1999, 5:467-475

44. Gouge RC, Marshburn P, Gordon BE, Nunley W, Huet-Hudson YM: Nitric oxide as a regulator of embryonic development. Biol Reprod 1998, 58:875-879.

45. Manser RC, Leese HJ, Houghton FD: Effect of Inhibiting Nitric Oxide Production on Mouse Preimplantation Embryo Development and Metabolism. Biol Reprod 2004, 71:528-533.

46. Zhao Y-C, Chi Y-J, Yu Y-S, Liu J-L, Su R-W, Ma X-H, Shan C-H, Yang Z-M: Polyamines Are Essential in Embryo Implantation: Expression and Function of Polyamine-Related Genes in Mouse Uterus during PeriImplantation Period. Endocrinol 2008, 149:2325-2332.

47. Rodriguez-Sallaberry C, Simmen FA, Simmen RCM: Polyamine- and InsulinLike Growth Factor-I-Mediated Proliferation of Porcine Uterine Endometrial Cells: A Potential Role for Spermidine/Spermine N1Acetyltransferase During Peri-Implantation. Biol Reprod 2001, 65:587-594

48. Gao H, Wu G, Spencer TE, Johnson GA, Li X, Bazer FW: Select Nutrients in the Ovine Uterine Lumen. I. Amino Acids, Glucose, and lons in Uterine Lumenal Flushings of Cyclic and Pregnant Ewes. Biol Reprod 2009, 80:86-93.

49. Hugentobler SA, Diskin MG, Leese HJ, Humpherson PG, Watson T, Sreenan JM, Morris DG: Amino acids in oviduct and uterine fluid and blood plasma during the estrous cycle in the bovine. Mol Reprod Dev 2007 74:445-454.

50. Leese HJ, Hugentobler SA, Gray SM, Morris DG, Sturmey RG, Whitear S, Sreenan JM: Female reproductive tract fluids: composition, mechanism of formation and potential role in the developmental origins of health and disease. Reprod Fertility Dev 2007, 20:1-8.

51. Gao H, Wu G, Spencer TE, Johnson GA, Bazer FW: Select Nutrients in the Ovine Uterine Lumen III. Cationic Amino Acid Transporters in the Ovine Uterus and Peri-Implantation Conceptuses. Biol Reprod 2009, 80:602-609.

52. Taylor $\mathrm{HS}$, Fei $\mathrm{X}$ : Emx2 regulates mammalian reproduction by altering endometrial cell proliferation. Mol Endocrinol 2005, 19:2839-2846.

53. Zhang $\mathrm{X}$, Chen $\mathrm{CH}$, Confino E, Barnes R, Milad M, Kazer RR: Increased endometrial thickness is associated with improved treatment outcome for selected patients undergoing in vitro fertilization-embryo transfer. Fertil Steril 2005, 83:336-340.

54. Gonen Y, Casper RF: Prediction of implantation by the sonographic appearance of the endometrium during controlled ovarian stimulation for in vitro fertilization (IVF). J In Vitro Fert Embryo Transf 1990, 7:146-152.

55. Sher G, Herbert C, Maassarani G, Jacobs MH: Assessment of the late proliferative phase endometrium by ultrasonography in patients undergoing in-vitro fertilization and embryo transfer (IVF/ET). Human Reprod 1991, 6:232-237.

56. Seidenfeld J, Block AL, Komar KA, Naujokas MF: Altered Cell Cycle Phase Distributions in Cultured Human Carcinoma Cells Partially Depleted of Polyamines by Treatment with Difluoromethylornithine. Cancer Res 1986, 46:47-53.

57. Nitta $\mathrm{T}$, Igarashi $\mathrm{K}$, Yamamoto $\mathrm{N}$ : Polyamine depletion induces apoptosis through mitochondria-mediated pathway. Exp Cell Res 2002, 276:120-128. 
58. Okazaki J, Komori K, Kawasaki K, Eguchi D, Ishida M, Sugimachi K: L-arginine inhibits smooth muscle cell proliferation of vein graft intimal thickness in hypercholesterolemic rabbits. Cardiovasc Res 1997, 36:429-436.

59. Albina JE, Cui S, Mateo RB, Reichner JS: Nitric oxide-mediated apoptosis in murine peritoneal macrophages. J Immunol 1993, 150:5080-5085.

60. Cornwell TL, Arnold E, Boerth NJ, Lincoln TM: Inhibition of smooth muscle cell growth by nitric oxide and activation of cAMP-dependent protein kinase by cGMP. Am J Physiol Cell Physiol 1994, 267:C1405-C1413.

61. Poulin R, Pelletier G, Pegg AE: Induction of apoptosis by excessive polyamine accumulation in ornithine decarboxylase-overproducing L1210 cells. Biochem J 1995, 311(Pt 3):723-727.

62. Jang M-H, Shin M-C, Jung S-B, Lee T-H, Bahn G-H, Kwon YK, Kim E-H, Kim C$\mathrm{J}$ : Alcohol and nicotine reduce cell proliferation and enhance apoptosis in dentate gyrus. Neuroreport 2002, 13:1509-1513.

63. Meresman GF, Augé L, Barañao Rl, Lombardi E, Tesone M, Sueldo C: Oral contraceptives suppress cell proliferation and enhance apoptosis of eutopic endometrial tissue from patients with endometriosis. Fertil Steril 2002, 77:1141-1147.

64. Sheng W, Wang G, Wang Y, Liang J, Wen J, Zheng P-S, Wu Y, Lee $\mathrm{V}$, Slingerland J, Dumont D, Yang BB: The Roles of Versican V1 and V2 Isoforms in Cell Proliferation and Apoptosis. Mol Biol Cell 2005, 16:1330-1340.

65. Takeda K, Kaisho T, Yoshida N, Takeda J, Kishimoto T, Akira S: Stat3 Activation Is Responsible for IL-6-Dependent T Cell Proliferation Through Preventing Apoptosis: Generation and Characterization of T Cell-Specific Stat3-Deficient Mice. J Immunol 1998, 161:4652-4660.

66. Harada T, Kaponis A, Iwabe T, Taniguchi F, Makrydimas G, Sofikitis N, Paschopoulos M, Paraskevaidis E, Terakawa N: Apoptosis in human endometrium and endometriosis. Human Reprod Update 2004, 10:29-38.

67. Vaskivuo TE, Stenbäck F, Karhumaa P, Risteli J, Dunkel L, Tapanainen JS: Apoptosis and apoptosis-related proteins in human endometrium. $\mathrm{Mol}$ Cell Endocrinol 2000, 165:75-83.

68. Tao X-J, Tilly KI, Maravei DV, Shifren JL, Krajewski S, Reed JC, Tilly JL, Isaacson KB: Differential Expression of Members of the bcl-2 Gene Family in Proliferative and Secretory Human Endometrium: Glandular Epithelial Cell Apoptosis is Associated with Increased Expression of bax. J Clin Endocrinol Metab 1997, 82:2738-2746.

69. Wyllie AH: Glucocorticoid-induced thymocyte apoptosis is associated with endogenous endonuclease activation. Nature 1980, 284:555-556.

70. Wyllie AH, Morris RG, Smith AL, Dunlop D: Chromatin cleavage in apoptosis: Association with condensed chromatin morphology and dependence on macromolecular synthesis. J Pathol 1984, 142:67-77.

71. Fulda S, Debatin KM: Extrinsic versus intrinsic apoptosis pathways in anticancer chemotherapy. Oncogene 2006, 25:4798-4811.

72. Lalier L, Cartron PF, Juin P, Nedelkina S, Manon S, Bechinger B, Vallette FM: Bax activation and mitochondrial insertion during apoptosis. Apoptosis 2007, 12:887-896.

73. Gross A, McDonnell JM, Korsmeyer SJ: BCL-2 family members and the mitochondria in apoptosis. Genes Dev 1999, 13:1899-1911.

74. Yu W, Sanders BG, Kline K: RRR-alpha-tocopheryl succinate inhibits EL4 thymic lymphoma cell growth by inducing apoptosis and DNA synthesis arrest. Nutr Cancer 1997, 27:92-101.

75. Shinoura N, Yoshida Y, Nishimura M, Muramatsu Y, Asai A, Kirino T, Hamada $\mathrm{H}$ : Expression level of $\mathrm{BCl}-2$ determines anti- or proapoptotic function. Cancer Res 1999, 59:4119-4128.

76. Cheng EH, Kirsch DG, Clem RJ, Ravi R, Kastan MB, Bedi A, Ueno K, Hardwick $\mathrm{JM}$ : Conversion of $\mathrm{BCl}-2$ to a Bax-like death effector by caspases. Science 1997, 278:1966-1968.

77. Kelekar A, Chang BS, Harlan JE, Fesik SW, Thompson CB: Bad is a BH3 domain-containing protein that forms an inactivating dimer with $\mathrm{BCl}-\mathrm{XL}$. Mol Cell Biol 1997, 17:7040-7046.

78. Yang E, Zha J, Jockel J, Boise LH, Thompson CB, Korsmeyer SJ: Bad, a heterodimeric partner for $\mathrm{Bcl}-\mathrm{xL}$ and $\mathrm{BCl}-2$, displaces bax and promotes cell death. Cell 1995, 80:285-291.

79. Kuwana T, Bouchier-Hayes L, Chipuk JE, Bonzon C, Sullivan BA, Green DR Newmeyer DD: BH3 Domains of BH3-Only Proteins Differentially Regulate Bax-Mediated Mitochondrial Membrane Permeabilization Both Directly and Indirectly. Mol Cell 2005, 17:525-535.
80. Datta SR, Dudek H, Tao X, Masters S, Fu H, Gotoh Y, Greenberg ME: Akt Phosphorylation of BAD Couples Survival Signals to the Cell-Intrinsic Death Machinery. Cell 1997, 91:231-241.

81. Hayes CS, DeFeo K, Lan L, Paul B, Sell C, Gilmour SK: Elevated levels of ornithine decarboxylase cooperate with Raf//ERK activation to convert normal keratinocytes into invasive malignant cells. Oncogene 2005, 25:1543-1553.

doi:10.1186/1477-7827-11-15

Cite this article as: Greene et al:: L-arginine enhances cell proliferation and reduces apoptosis in human endometrial RL95-2 cells. Reproductive Biology and Endocrinology 2013 11:15

\section{Submit your next manuscript to BioMed Central and take full advantage of:}

- Convenient online submission

- Thorough peer review

- No space constraints or color figure charges

- Immediate publication on acceptance

- Inclusion in PubMed, CAS, Scopus and Google Scholar

- Research which is freely available for redistribution 